\title{
11
}

\section{Pathways and processes towards a gender equality policy}

\author{
Meredith Edwards and Miranda Stewart
}

All aspects of government action and policy have gender implications. The federal Office for Women has identified three areas of focus for Australian Government policy on gender: (1) women's safety from violence; (2) representation of women, for example on decision-making boards and in politics; and (3) economic empowerment. This volume presents new and important research about gender inequality in Australia's tax-transfer (welfare) system, including theoretical, empirical and policy analysis of this theme. The research in this volume aligns in particular with the goal of women's economic empowerment, which is highlighted by the Office for Women as 'an economic and social priority. It's good for women and their families, their communities, business and the nation's economy' (Office for Women 2016). The Minister for Women, Senator Michaelia Cash, has emphasised policies to support women at the G20 (Cash 2014) and, in particular for parenting and domestic violence, in a statement accompanying the 2017-18 Budget (Cash 2017). However, gender impact remains marginalised in Australia's budget. The most recent Budget Papers (Treasury 2017) do not contain any gender impact analysis of policy. This is in stark contrast to the recent Canadian budget (Government of Canada 2017). 
The first part of this volume presents international and comparative principles, context and benchmarks on gender equality by Kathleen Lahey (Chapter 2); a holistic economic approach to gender equality to produce an efficient, equitable and fiscally sustainable tax-transfer system by Patricia Apps (Chapter 3); and a human rights framework that incorporates gender equality as a core element of macro-economic fiscal policy (Hodgson and Sadiq in Chapter 4).

The focus then turns to a policy analysis of unequal effects of current policy on women's economic security. A key element is the engagement of women in paid (market) work. Government policy aims to 'support more Australian women into work, improving their economic security today and to accumulate retirement savings for the future' (Office for Women 2016). To achieve this without further disadvantaging women, government policy must take the gendered issue of care work seriously. The implications for women's paid work of the intersection of government policies over the life course is examined by Guyonne Kalb (Chapter 5), while the inadequate recognition of unpaid or household care work by women in the historical and contemporary Australian welfare state is discussed by Julie Smith (Chapter 6).

Subsequent chapters present novel empirical research addressing the different ways in which men and women balance work and child care time (Huong Dinh and Maria Racionero in Chapter 7); the unequal gender returns to education through earnings and the impact of Australia's higher education financing scheme (Mathias Sinning in Chapter 8); the position of women at the top of the income distribution (Miranda Stewart, Sarah Voitchovsky and Roger Wilkins in Chapter 9); and the implications of retirement and age pension policy for adequacy of women's incomes in old age (Siobhan Austen and Rhonda Sharp in Chapter 10).

In this concluding chapter, we return to the central role of government policy and discuss pathways and processes to achieve a gender equality policy in the future. The chapters in this volume clearly demonstrate the persistence of gender inequality and show the critical role played by government policies, especially tax-transfer policies, in both reproducing and alleviating this gender inequality. The research presented also provides clear directions for policy in Australia's tax-transfer system to achieve women's economic empowerment, thereby contributing to greater wellbeing for all in Australia. The persistence of gender inequalities across a range of public policy areas indicates a continuing need for 
gender-focused policy processes. We discuss past governmental processes for achieving gender equality and then turn to consider the pathways and processes to achieve gender equality in future government policy. In particular, we consider the question of gender budgeting, including impact analysis and policy formulation through a gender lens.

\section{The ups and downs of gender budgeting in Australia}

Gender budgeting is a formalised institutional process that incorporates gender analysis of budget measures and indicators, in government agencies, departments and at Cabinet level, and which may be carried out at various levels of policy formulation, financing and delivery. One widely used definition is:

[A] gender-based assessment of budgets, incorporating a gender perspective at all levels of the budgetary process and restructuring revenues and expenditures in order to promote gender equality (Council of Europe 2009).

Gender budgeting starts from the proposition that the budget is the central political document that activates government policy by raising revenues and allocating expenditures legislated by the parliament. Within agencies and departments tasked with developing policy and delivering public goods and services, performance budgeting generates a process of tracking policy through to outcomes that can incorporate targets, indicators and measures of achievement on gender equality.

Political action for women's rights has a long history. However, the process of gender budgeting has its origins in Australia during the early 1980s. The circuitous institutional pathways and fortunes of feminist engagement in the Commonwealth bureaucracy, traced by Marian Sawer (1990) are of particular interest to us as the Commonwealth has primary responsibility for broad taxation, social welfare, wages, retirement and higher education policy. During this time, the 'femocrats' (Sawer 1990; Watson 1990; Eisenstein 1996) sought to introduce and embed genderequal policies; to examine distributional impact and demonstrate where it was unequal in respect of gender; to identify the fiscal cost and extremely high effective marginal tax rates for many women produced by tax-transfer interactions; and to fend off or reduce the impact of policy proposals that 
would undermine gender equality. They made the case in government that unequal gender and class outcomes were the direct result of tax-transfer policies as well as labour market discrimination and care responsibilities of women. They also showed that government policies could change to support gender equality, address poverty and improve work incentives.

Not surprisingly, the pathway towards achieving gender-equal policy has not been easy and remains challenging and incomplete. The best process is not always easy to identify, and both actions and outcomes have often been marginal or partial. On some indicators, progress has been striking. For example, the aggregate proportion of women in tertiary education is today greater than the proportion of men. Yet, even in this field, the sex-segregation of women and men in fields of tertiary study remains significant and differential outcomes remain. As Sinning shows in Chapter 8, the economic (wage and earnings) return to women for investing in their human capital through tertiary education or technical further study is significantly lower than for men.

Successes or setbacks in gender-equal policy and processes have not always followed a simplistic 'left/right' divide in politics. After activism and government appointments in the early 1970s under the Whitlam Labor Government, the establishment of an office for Women's Affairs in the central Department of Prime Minister and Cabinet (DPMC) occurred in the early years of the Fraser Liberal-National Government. The Women's Affairs office had a say on all Budget submissions, noted by Sawer as one of the most important aspects of its work (Sawer 1990, p. 46). However, in the late 1970s, the Women's Affairs office was demoted to an 'outer' government department, although substantial work continued to be done 'behind the scenes' even in this location.

The Office for Women was reinstated in the central department in 1983 under the Hawke Labor Government and it was during this time, under leadership of Anne Summers, that the Office developed an innovative approach to gender impact analysis to identify and track the effects of policy on women and to recommend directions to improve gender equity. The first Women's Budget Statement was released in 1984, and it was produced in a fairly detailed format until 1996. As has been internationally acknowledged, Australia was a pioneer in this analysis (Sharp and Broomhill 2013). Nevertheless, under the Labor Government of the 1980s and the Liberal-National Party Government of the previous 
decade, the central economic department of the Treasury resisted engagement with gender equality analysis and never participated directly in the Women's Budget Statement.

The requirement established in 1983 that all Cabinet submissions were to include a statement about impact on women was removed after four years (Sawer 1990, p. 71), even as Australia prepared a National Agenda for Women to the Year 2000 in response to international developments in the United Nations. The late 1980s also saw increasing targeting and means testing of family and child payments for fiscal reasons, undermining the goal of achieving women's workforce participation. The Women's Budget Statement and role of the Office for Women was further demoted in scope and importance under the Howard Liberal-National Government during the mid-1990s. In the early 2000s, it moved the Office for Women out of DPMC and into the Department of Family and Community Services. This major government department was responsible for family payments and social security policy, which had significant implications for women. Some had suggested that this could be perceived as a move of 'so-called women's issues into the mainstream' (Goward 2004), so that gender would be more comprehensively considered in key programs in the public sector. ${ }^{1}$ However, it effectively demoted gender equality and did not lead to a fully comprehensive analysis of gender in tax-transfer systems; arguably, the reverse happened, and the Office lost its crossgovernment coordinating role in the process.

Even under Howard's more socially conservative government, in 2006 Julie Bishop, then Minister Assisting the Prime Minister for Women's Issues, emphasised Australia's commitment to gender equality including budget analysis (Bishop 2006); in that year, the Office for Women released Women '06: 2006-07 Budget Information. The Australian Bureau of Statistics (ABS) also in that year conducted and released the results of a major Time Use Survey (TUS) (the largest ever conducted in Australia), which dramatically demonstrated the gender differences in market and household work and care of women and men (ABS 2006). The 2006 TUS provides crucial data for researchers on gender and care. It is relied on in Chapter 7 (Dinh and Racionero) and is referred to in numerous other chapters of this volume (see also Baird et al. 2017). However, this

1 On the complexities of gender 'mainstreaming' in Australian Government policy see Walby (2005); Bacchi and Eveline (2010). 
survey has not been funded since 2006, and the scheduled survey of 2013 was cancelled, in a broader context of ongoing cuts to funding for data collection and analysis in the ABS and other government agencies.

The Labor governments of 2007 to 2013, including under Australia's first female prime minister Julia Gillard, reinstated a Women's Budget Statement, which did an overview of government policies aimed at women's equality. However, it was relatively superficial and these governments did not bring gender analysis back into the central government agency or reinstate the role of the Office for Women in cabinet processes or as a coordinating agency. More than 30 years after the first Women's Budget Statement was released in 1984, we saw its abandonment in 2014 by the Abbott LiberalNational Government; in the last few years, gender budgeting and gender impact analysis seemed to disappear from Australian Government policy processes, except in the arena of foreign aid, where gender indicators for development still retained a foothold (again under the leadership of Minister Julie Bishop). The Australian Labor Party (ALP) in opposition has continued a tradition of producing a Women's Statement, which is valuable, albeit inevitably restricted to the statement of ALP policy on gender and limited analysis of government policy. Outside government, the most important and comprehensive gender analysis of the budget is carried out by the non-government National Foundation for Australian Women (NFAW), which has since 2014 put a gender lens on the budget ex post, with minimal resources (most recently, NFAW 2017).

While gender impact analysis seems to have disappeared from the government agenda, gender remains centrally relevant to much government policy. As discussed in Chapter 1, in the last few years we have seen governments of both stripes introduce and debate major funded policies for paid parental leave, child care policies, income tax rate structures for workers, social welfare and family payments, elder care, pension and retirement policies and disability policy. A central element in these policies is sharing the fiscal cost of care. These policies, which have implications for the wellbeing of the wider population of men, women and children in Australia, have direct and fundamental implications for gender equality. 


\section{A tax and transfer reform agenda for gender equality}

There is, of course, a diversity of views about how best to achieve gender equality goals and women's economic empowerment, including increased workforce participation and economic security, and what pragmatic policies and priorities are needed. Nonetheless, we identify a clear consensus among our expert contributors on the needed policy direction to achieve gender equality, arising out of the detailed theoretical, policy and empirical analysis in this volume.

\section{A progressive income tax}

The first recommendation is to maintain and enforce a progressive income tax as an efficient and equitable tool for gender equality. A progressive income tax on individuals with marginal rates that rise as income rises is important for women's equality because women earn less than men. As explained in Apps (Chapter 3), Kalb (Chapter 4) and other chapters, a progressive income tax is both efficient (taxing less responsive higher income earners more highly) and equitable, being based on ability to pay. The tax system operates in the context of gender-unequal workforce outcomes in both wages and hours, and with the lion's share of part-time work done by women. As lower wage or secondary earners in households, women's workforce participation is supported by a progressive income tax, which taxes the lower wage earner at a lower rate.

Feminist advocacy to maintain the progressivity of Australia's personal income tax has a long history and played an important role during the 1980s era of tax reform. The National Women's Tax Summit was convened by the Women's Electoral Lobby (WEL) one week before the famous Tax Summit 1985, ${ }^{2}$ which brought together the government, labour and business leaders to debate major tax reform process, influenced by international trends including in the United States and United Kingdom (under Reagan and Thatcher). Described as 'the first national mobilisation of women over an economic issue' (Sawer 1990, p. 93), the Women's Tax Summit included representation from a wide range of women's organisations across all sectors of the community and economy and it

2 For a summary and document references, see National Archives of Australia, Tax reform, www. naa.gov.au/collection/explore/cabinet/by-year/1984-85/tax-reform.aspx. 
resoundingly repudiated 'Option C' (Treasury 1985), which included a tax mix shift from the progressive income tax to a broad-based consumption tax with significantly lower marginal tax rates. In light of recent research into growing inequality across countries and the role of the top tax rate in producing and reinforcing income inequality (Atkinson and Leigh 2007; see discussion in Chapter 9), the retention of a reasonably high top tax rate by Australia has contributed to Australia's relatively equal disposable income distribution.

The progressive income tax is also highly effective at raising revenue in Australia. Women as a class benefit from public expenditure that delivers government services and public goods to all. The question of whether Australia requires more revenue-higher taxes-to fund government in the future remains of central importance in Australian fiscal policy debates. This may require both raising tax rates and broadening the tax base, including income, consumption and wealth taxes, as we see increasing demands on public expenditure for disability, age care and early childhood education, as well as infrastructure. It is worth observing the approach of the Nordic states, which levy both highly progressive income taxes and broad-based consumption taxes to fund their welfare states and also produce the most gender-equal outcomes globally.

\section{The individual unit in tax and transfer systems}

Second, this volume supports an individual unit as the basis for taxtransfer systems as far as possible but, in particular, where there are caring or dependant responsibilities. We must keep a clear policy focus on women as individuals making decisions, doing care work, bearing tax burdens and receiving benefits in the tax-transfer system and in family, work and care economies. This requires us to pay attention not only to the income tax but also to the design of payments, thresholds and means tests in the welfare system and public policy for child care and families.

The tax-transfer system has a particularly close relationship with women's economic security and empowerment and, specifically, women's workforce participation. Current tax-transfer policies make it rational for one person in a family, almost always a woman, if raising children or with other carer responsibilities, not to work in the market or to work only part-time. This reduces women's chances of remunerative and rewarding work and economic security in the longer term and undermines the government's stated goal of achieving economic independence, wellbeing and lifetime 
security for women. There is little evidence of a willingness to share time and cost of care between women and men, which would also then share the cost and risks of time taken out of the workforce to do caring and other household work. Recent research indicates that there are significant time, stress and public health implications of the 'extra' time burden of care on top of paid work for women, while still at relatively low incomes (Dinh et al. 2017).

The federal income tax has always had an individual unit in Australia. However, the testing of family and other transfer payments on household or couple income produces a 'quasi-joint' unit especially for women caring for children. At the top end of the income distribution, Chapter 9 (Stewart, Voitchovsky and Wilkins) presents evidence of income splitting in Australia's income tax, producing a 'quasi-joint' unit for high-income families, undermining the individual income tax base. Income splitting produces a lower tax burden for high-income families by using the progressive income tax rate structure, and the benefit has increased as a result of the increase of Australia's tax-free threshold and other rate thresholds in 2012. The use of low-taxed self-managed superannuation funds and discretionary family trusts is widespread and may be combined with the low tax rate applicable to capital gains and other tax planning approaches. As a result, Australia's income tax base is too narrow and a reform to broaden the individual income tax base would be positive for gender equality.

The interaction of the income tax system and the means-tested transfer system has proven to be a major sticking point for gender-equal policy over the last 30 years in Australia. Governments have tightened the means testing of most social welfare payments, to a point where Australia has the most tightly targeted welfare system of any Organisation for Economic Co-operation and Development (OECD) country (Whiteford 2016). The means testing of social welfare benefits on which women rely, at least while they are of working age, would ideally be done on an individual basis; alternatively, relevant benefits supporting the cost of care could be provided universally or with a high income-free area. This would encourage gender equality in workforce participation, with likely long-term benefits for economic growth and taxes. However, it comes at an immediate fiscal cost. The provision of universal benefits is seen as delivering unaffordable 'welfare' to middle-class and upper-income households. The 'iron triangle' (Henry et al. 2009) of means testing family and child care payments, 
individual income tax rates and an overarching fiscal or expenditure constraint sets gender equality directly against traditional concepts of vertical equity and horizontal equity in tax and welfare design.

The assumption that the household is the correct unit for means testing of transfer payments assumes that income and consumption is shared in the household and that women benefit equally from consumption inside the family. Clearly, some major forms of consumption (such as housing or electricity) can usually be assumed to be shared. However, empirical evidence shows that shared consumption even of food and household goods, and certainly of luxuries or leisure, is not always true (as demonstrated in Edwards 1981). Recent news stories about the lack of sharing of consumption when women stop work to look after children indicate that it cannot be taken for granted (Dunning 2017). Moreover, families, households or relationships are not static, and women's economic security is significantly threatened by separation and divorce. The traditional concept of horizontal equity that treats married couples more favourably than single people on the same income or treats a married or partnered woman as a dependant can no longer apply; in other words, all taxpayers on the same income irrespective of their marital status should be treated equally. Horizontal equity in the tax-transfer system should, however, recognise the cost of care and treat taxpayers with children, or, perhaps, other care responsibilities, differently from those without such responsibilities, as facing greater direct and indirect costs and lower capacity to pay.

\section{Public funding for the cost of care}

The issue of care remains a 'barbeque stopper' in John Howard's words (quoted in Heron et al. 2017, loc. 4496). A major comparative study shows that Australia today has a family-centred care regime underpinned by significant financial assistance from the state. Parents, in particular mothers, provide most child care, with the assistance especially of grandparents, and daughters (who are often also mothers or grandparents) provide the bulk of care for elders (Heron et al. 2017, loc. 4522). Policies to put more women into the paid workforce for more hours will not achieve gender-equal outcomes unless the cost of care is supported and tax-transfer policies that intersect with labour market programs are adjusted. After more than 30 years of public policy in building child care provision, labour programs and other measures aimed at encouraging 
women's workforce participation, it is clear that the best chance of success is in providing wide public support for parental leave and child care for women of prime working age (between 20 to 45) and implementing clear policies to share care and connection of children between women and men.

We need to share the fiscal cost and time of care more equally between women and men, and across society via our tax-transfer system, to achieve gender-equal opportunities and outcomes. As discussed by Julie Smith (Chapter 6), it is necessary to acknowledge and support the (unpaid) caring work done mostly by women, ranging from infant care, nutrition by breastfeeding and child rearing through to elder care. We should be encouraging paternal primary care and supporting the value of personal familial care in other situations, of sickness, disability and old age.

It is also important to acknowledge the reality that at present (and perhaps for the foreseeable future) the labour market frequently does not offer attractive choices for women. As Sinning (Chapter 8) shows, women especially those with fewer skills (such as technical certification skills), obtain almost no wage or earnings benefit compared to those who only complete school education; while women doing postgraduate study are no better off, from an earnings perspective, than those who complete a degree. Many women never earn enough to repay their Higher Education Contribution Scheme (HECS) debts for higher education. Current policies are failing to harness this pool of skilled and educated labour for the greater good. It is hardly surprising, in this context, that many women even with further education may prefer to work in the family and raise children or rely on flexible, part-time jobs while also doing caring and other non-market work.

The quality of care, of children and elders, matters to Australians. We also need to take account of the research showing that men and women may make different decisions about balancing child care and work that can impact on both children's and parent's wellbeing (Dinh and Racionero, Chapter 7). A system of paid parental leave is an investment in women's workforce participation and in the current and future health of children and mothers, contributing significantly to the economy as a whole. It may need to be made compulsory for men if the current allocation of care responsibilities is to change. If we do not acknowledge this, current and proposed tax and welfare reforms may not shift fundamental discourses 
around the family, the market, time and happiness, or may change these in ways that are suitable for the market economy but have unexpected, and still-gendered and oppressive, consequences.

\section{Security in retirement}

A life course approach to gender equity requires us to examine how women are situated at retirement age. Women are more than 60 per cent of age pensioners and have much less in private retirement savings than men. Siobhan Austen and Rhonda Sharp (Chapter 10) demonstrate that a retirement policy that links security in retirement either solely to waged workforce participation over the working life, or requiring dependence on a male partner for support in old age, is detrimental for gender equality. The issue is also referred to in a number of other chapters in this volume. As noted in the subtitle to the Senate Economic References Committee's Inquiry into Women's Economic Security in Retirement (2016), 'a husband is not a retirement plan'. A gender budget analysis reveals the benefits and burdens of the current retirement savings, tax and welfare policy that is skewed towards tax concessions for retirement saving in superannuation.

\section{The importance of policy process: 10 points}

In gender policy process and institutions, Australia now lags behind other OECD countries, when once it was in the vanguard. A recent OECD report on gender budgeting describes Australia as having no gender budgeting process planned (OECD 2016, Fig. 1, p. 9). The OECD found that, apart from the occasional specific program and the gender indicators produced by the ABS, Australia does not have a systematic process to assess the impact on women and men of taxing, spending or government programs, either before or after the government enacts legislation, appropriates funds or initiates policy. Indeed, Australia was ranked equal last with Slovakia in terms of gender impact analysis requirements (OECD 2014a, p. 185) and it compares poorly with many Asia-Pacific countries on this issue. In the last decade, the federal government has lost data, capability, networks, analytical capacity and commitment to gender impact analysis. However, we argue that there is significant scope for rebuilding and reformulation of gender capacity in the policy process in Australia. We know from long experience that policy process both tactical and strategic is critical (Edwards 2001). 


\section{Context matters}

Tying any policy agenda to the government's current priorities is likely to get it a better hearing. We must be politically pragmatic while being cautious about going backwards in key indicators. The economic agenda is always important—such as a government focus on improving productivity and increasing the workforce participation of women. This is a good topic on which to raise the importance of unpaid work as a substitute in time for paid work and the policy implications of that (see Chapter 3 and Chapter 6, this volume). The tax and social policy agenda of ensuring 'fairness' (committed to by Prime Minister Turnbull) is also a valuable hook. However, the government's concern about fiscal constraint also needs to be taken into account and the continued emphasis on expenditure constraint is ominous for gender equality.

In moving from 'what' to 'who' to influence, currently the Minister for Women is also the Minister Assisting the Prime Minister on the public service as well as being Minister for Employment, which has to be a plus. A key role can be played by the Office for Women, in its newly relocated central position in DPMC, to find the right balance between government and the non-government women's sector and the next steps in the government-NGO-researcher relationship.

\section{Clarifying the problem}

The problem we want government to confront needs to be clarified, articulated well and then owned by the public and ultimately by policymakers. Only once the issue is identified as a policy problem do people then ask, 'what can we do about it?' You cannot get policy change without this first step in the policy process. In the radical child support reforms of the 1980s, it was relatively easy to articulate the problemwhy should taxpayers foot the bill just because parents decide not to live together? By way of contrast, in the case of the National Housing Strategy review in the late 1980s, the focus was on the problem of high financial housing stress for low-income renters, which proved too hard at a time when many citizens were faced with very high interest rates on their mortgage payments. 
One area of policy in the tax-transfer area that requires attention to clarify the problem is the high wage elasticities faced by women compared to men. Female employment is very likely to fall if disposable income increases only minimally for market wages that women earn, after costs of working and the effect of the tax-transfer system.

\section{The power of data and evidence}

It is unrealistic to expect 'evidence-based policy' when policy and politics mix. However, evidence-influenced policy can lead to both good policy and good politics. Having identified the problem, ascertaining what data and evidence can be brought to its analysis is critical. In spite of the current anxiety about 'alternative' facts, in this era of 'big data' and the increasing use and open publication of data sources, we suggest that the climate now is more receptive to the use of evidence in the policy process than it was a few years ago. In this context, we emphasise that disaggregation of data by gender is essential for policy, and to assert that while data is all around us, there is an ongoing problem of a lack of generally available, accessible and affordable data on gender impacts of policy. Part of our argument will be the need for government to be accountable for its stated intended outcomes and international commitments and be more transparent to parliament, to citizens and the broader international community. What gets measured counts. The importance of this issue has been observed by the OECD in noting that, 'The routine availability of gender-specific data sets and statistics would greatly facilitate the evidential basis for the identification of gender equality gaps, design of policy interventions, and the evaluation of impacts' (OECD 2016, p. 3).

The ABS and Office for Women are now highlighting more regularly a range of interesting gender statistics about women in the Gender Indicators; this is to be encouraged and should be expanded in future (ABS 2016). The chapters in this volume demonstrate the creative use of data sources to reveal patterns of gender inequality across a range of different government policies.

One important source, as noted above, is the TUS (ABS 2006). We are concerned about the cancellation of the TUS that was scheduled for 2013. The OECD has recently collated time use data from most member states and some additional countries including China, India and South Africa (OECD 2014b). This reveals more recent surveys in some countries (for example, Canada in 2010 and the United States in 2014). The development 
and roll-out of a new TUS would contribute to our knowledge about the practices of family and social care within Australian households. This is revealed in time choices about child care by women and men and other family members; how this applies for other kinds of care responsibilities; and decisions about sharing work and care a decade later, so as to design and evaluate policy for contemporary Australian families.

Some kinds of data relevant to analysing taxes and transfers are collected on a household basis, which obscures the treatment of women as individuals in families, including the ABS Household Income and Expenditure Surveys on income and wealth. In contrast, income tax data is collected on an individual basis, and research based on tax aggregate and administrative data has potential to tell us more about the impact of tax systems on women. This resource is the basis for the research by Stewart, Voitchovsky and Wilkins (in Chapter 9) on top incomes of women.

When the environment is receptive, evidence can be powerful both in clarifying a problem and in moving toward a solution. But, again, how the data and evidence is communicated and to which audience matters. Knowledge brokers may be needed to translate to busy policymakers what can otherwise be dense academic research (see Bammer 2010). We have identified some important areas for further policy-related research in this collection. One of these relates to wage and child care elasticities by age, income and education level as well as gender (see various contributors in this volume; and Productivity Commission 2015). Although the previous government established a joint Treasury-Department of Social Services (DSS) working party on tax-transfer system interactions, this task seems to have been sidelined and should be reinvigorated.

\section{Value of international comparisons}

Our agenda can also be tied to Australia's international commitmentsG20, Convention on the Elimination of All Forms of Discrimination Against Women (CEDAW) and Sustainable Development goals. As discussed by Hodgson and Sadiq (Chapter 4) and Lahey (Chapter 2), Australia has international obligations, in particular about workforce participation and children, in the G20 and OECD. The centrality of gender equality including measurement and impact analysis in the United Nations Sustainable Development goals, and the growing interest in gender analysis in countries around the world, provides us with an important lever for activity. There is a role for international comparisons 
with approaches of other countries more broadly on gender analysis, both for ourselves in this country and as policy leaders internationally. Related is the value of evidence about better practice, especially overseas comparisons. These were particularly valuable in research on possible child support reform (see, for example, Edwards 2001). There is substantial value in comparisons, but in the end it must be recognised that Australia's policy and budget process is highly path dependent.

The concept of gender budgeting is being reinvigorated internationallyin the OECD, International Monetary Fund (IMF) and in recent developments in country governments and non-government activity. In Canada, the federal government included gender analysis in the core budget documentation for the first time in 2017 (Government of Canada 2017), incorporating the gender equality indicators and goals as part of a broader statement of better economic policy and fairness to build a stronger Canadian middle class. Such an approach with a clear gender element would likely resonate in Australia. There has also been significant work by budget analysts such as the UK and Scottish Women's Budget Groups, working within and outside government. Austen and Sharp in Chapter 10 demonstrate the value of a gender impact analysis of retirement policy, examining the policy goal of adequacy of retirement incomes for women. The OECD points to various gender budgeting approaches in different countries including ex ante analysis of individual budget measures to identify the impact on gender equality; bringing a gender perspective to performance budgeting of government departments; to resource allocation and in incidence analysis of benefits and burdens. An ex post gender impact assessment, or gender baseline analysis or audit of the budget is also applied in some countries (OECD 2016, pp. 7-8).

\section{Importance of dialogue}

Dialogue is critical, including between policymakers and researchers; between policymakers and those who deliver services; and between policymakers and civil society, researchers and politicians. It is critical for academic researchers to understand the importance of dialogue for getting ideas across - for example, round tables, tailored to issues of concern to the government of the day, rather than just an article, a chapter or a book. The empirical research presented in this book is an important input to public policy. However, busy policymakers are more likely to 'google' to gain information than read what researchers have to say. There is a real conflict 
here for academic researchers with the incentive structures in universities that emphasise publications in quality journals, but the evidence is very clear on what is needed to best gain research impact and it is not the written word as much as dialogue and exchange of information based on trusted networks that work (e.g. see Nutley et al. 2007; Edwards 2010; Head 2013).

The Office for Women is in an excellent position to reinvigorate its coordinating role across government and with non-government organisations and academics. Through linking research, policy and practice, the Office for Women can lead in developing discussion about potential policies to build women's' capabilities, helping decision-makers meet such challenges. It will be necessary to reintroduce the expertise and training mechanisms for integrating gender analysis across government departments. This calls for combining effective consultation and evidencebased policies from inside government, given especially the inadequacy of funding, resources and access to data of external volunteer organisations such as NFAW.

\section{Power of networks and relationships}

Who you know and in what context can lead to effective relationships when that is needed across the research, policy and political divides. Networks, relationships and strategic cross-sector collaboration are vital. Engagement with external activists such as the WEL taught the early femocrats the power of women's networks that could later be used to advantage both inside and outside of government. It meant, for example, when dealing with sensitive child support issues, ideas and possible policies could be tested among networks knowing that confidence would be respected. The value of networks and past working relationships was also critical when Bruce Chapman and Meredith Edwards (Keating 1994) advised on policies for the long-term unemployed in the 1990s, having previously worked on developing HECS. A trusting relationship helped to cut the time that was needed to convince those in influential policy positions of desired employment policy options.

\section{Strategic cross-sector collaborations}

Collaborating to form alliances with others from inside government to the outside and vice versa is now the main game if any complex policy issue is to be resolved. But a strategic approach is needed: about why 
collaboration is needed, when to do it, with whom and how. It may mean upfront informal bilateral discussions followed by broader collaborations depending on the sensitivity and complexity of the issue. Increasingly as governments, in the interests of short-term politics, avoid good policy and policy processes for the longer term on key concerns of the public (such as housing issues), alliance of non-government players across business, union and relevant not-for-profit organisations may force governments to act.

In terms of the agenda in this volume, there is a place not just for women's groups inside and outside of government (such as the NFAW, National Council of Women in Australia, UN Women, YWCA, the Workplace Gender Equality Agency, female politicians) but also for others such as the Academy of Social Sciences Australia, the Australian Human Rights Commission, the ABS, National Centre for Social and Economic Modelling (NATSEM) at the University of Canberra, and the ANU Tax and Transfer Policy Institute and Centre for Social Research and Methods. Depending on purpose and timing, at a certain stage we could take the collaboration wider; for example, to a parliamentary committee to gain political buy-in or to a Fairfax/Australian-type public forum. We might consider forming an independent unit to assess and monitor women's initiatives (such as the Women's Budget Group in the UK).

\section{Be politically pragmatic}

The scale and targets of gender analysis should be tailored to the political environment. The NFAW in its 2015 Gender Lens on the Budget recommended that '[a]ll budget measures should contain gender equity objectives and indicators and performance measures disaggregated by sex' (NFAW 2015). While not losing sight of this longer-term goal, it is important to go for the possible; to nudge forward to the ideal while ensuring that our incremental steps do not conflict with that ideal. Valuable research papers on gender impact analysis are available, including Sharp and Broomhill (2013), and that is part of our armoury, while the ALP in Opposition has committed to restoring annual Women's Budget Statements if returned to government. Today, we need to start in a more focused manner until we can gather a momentum around why gender impact analysis is such an essential part of developing good policy and delivering good policy outcomes as well as gender equality. 


\section{Beware of going backwards}

We do not need to dwell on the danger of going backwards. Many examples have been given of this in this volume and at the workshop that inspired it. These include shifting from universality to means testing of family allowances and the ongoing challenge of fiscal austerity policies as explained by Kathleen Lahey in Chapter 2; the more than 10-year gap since the last ABS TUS; the improved but still-limited and cost-constrained policies for the financing and length of paid parental leave, child care and early childhood education; and the gender wage gap. History is important but its gains are easily lost in this age of high job turnovers of government personnel. It is valuable to be reminded by Marian Sawer and others about what has been and can be again.

\section{Starting point: Institutions to support collaboration}

We propose building institutions to support collaboration on genderequal policy by relevant parties across government, research and nongovernment spheres. We could contribute to mapping the data gaps if we want to engage in gender budgeting and more broadly gender impact assessments, both ex ante and ex post in relation to priority policy issues, and to determine the role that various organisational participants might play to assist in meeting those gaps and in the needed gender analysis. A possibility could be establishment of an advisory roundtable coordinated by the Office for Women, including representatives from the key women's organisations and broader organisations identified in Section 7, together with government participants from DPMC, Treasury, ABS, Australian Institute for Health and Welfare, and the Department of Social Services. Informal conversations, first with a few inside the bureaucracy to gauge what is possible and who could most usefully initiate the dialogue, followed by a roundtable using the Chatham House rule to get priorities for action and a commitment to that action.

\section{Conclusion}

The goals of good gender analysis of budgets and public policy are also goals of good modern budget governance in general: 'the need for clear, multi-dimensional budgetary impact analyses, and the need for evaluation frameworks that feed directly into the policy and budget cycle' (OECD 2016, p. 4). A gender lens is critical to produce gender-equal policy. The 
persistent gender inequalities in Australia across the broad policy areas of taxation, welfare, work, education, child care and retirement require an explicit focus on gender in impact analysis and policy design. This requires critical analysis both within and outside government, both ex ante and ex post budget decisions, building and using data and evidence in policy design and evaluation and including academic and civil society contributions throughout the process.

If it is to be successful, government policy aimed at women's economic empowerment requires data, analysis and clever policy design across all the areas of tax and transfers, wage equity, superannuation and financial literacy, child care and paid parental leave, education, flexible work places and putting women in non-traditional roles (Office for Women 2016). A gender-equal policy will also require governments to pay attention to the work and caring roles of men as well as women, so as to build a flexible approach to work, care and education over the life course of all individuals and their families. More fundamentally, as the nature of work changes and economic security for all becomes an increasing challenge, a policy that supports gender equality over the life course can show the way for a new approach to public and private provision that builds economic empowerment for all.

We need to renew Australia's commitment to best practice with respect to gender impact analysis that comes early in the policy process, not after the fact. A Women's Budget Statement should be included with the budget. This could be comprehensive, covering all spending and taxing and containing detailed modelling about the distributional, social and economic impact of government policy; however, even the earliest such Statements in the 1980s did not achieve this comprehensive goal. A more focused approach seems better for today's times, for example targeting a goal that is a current focus of government policy (such as women's economic empowerment) and analysing all aspects of government taxes, spending and programs to understand the impact on that policy goal; or selecting major indicators on which to focus.

Governments of different political persuasions today appear to recognise the importance of key investments in human capital including child care (but not, yet, a full right to early childhood education); parental leave; equal wage policy; the sharing of public responsibility for disability and elder care; and the need for a secure retirement for women. This is promising, but there is a continued perception that care is a 'women's 
issue'. This framing of the issue is not merely rhetorical. It is enacted in real fiscal constraints and budgetary limits reflecting the ongoing refusal of the government to share the cost of care through the significant tools at its disposal in the tax-transfer system. This raises questions about the commitment to gender equality, and it also seems to indicate a narrow and short-term view of the fiscal cost of addressing inequality and the broader economic and social benefits of so doing. Re-engaging gender analysis, evaluation and research insights in policy processes will improve outcomes on this issue and others, for women and Australian society as a whole. As indicated in the 10 policy principles and issues set out above, we need to be both visionary and pragmatic; take a systemic view and strategically focus on specific issues to deliver real policy change.

\section{References}

ABS (Australian Bureau of Statistics). 2006. How Australians Use Their Time-2006. Publication 4153.0. Available at: www.abs.gov.au/ ausstats/abs@.nsf/mf/4153.0

ABS. 2016. Gender Indicators, Australia-August 2016. Publication 4125.0. Available at: www.abs.gov.au/ausstats/abs@.nsf/mf/4125.0

Atkinson, Tony and Andrew Leigh. 2007. 'The Distribution of Top Incomes in Australia', Economic Record, 83(262): 247-261. doi. org/10.1111/j.1475-4932.2007.00412.x

Bacchi, Carol and Joan Eveline (eds). 2010. Mainstreaming Politics: Gendering practices and feminist theory. Adelaide: University of Adelaide Press. Available at: www.adelaide.edu.au/press/titles/mainstreaming/ Mainstreaming-Ebook-final.pdf

Baird, Marian, Michele Ford and Elizabeth Hill (eds). 2017. Women, Work and Care in the Asia-pacific. Routledge: London and New York. Kindle Edition.

Bammer, Gabriele (ed). 2010. Bridging the 'know-do' gap: knowledge brokering to improve child well-being. ANU E Press: Canberra. 
Bishop, Julie. 2006. 'Gender Budget Analysis: Australia's Commitment to Gender Equality', The Parliamentarian 2006/Issue Three, pp. 201204. Canberra: Commonwealth Parliamentary Association. Available at: www.cpahq.org/cpahq/cpadocs/Australia\%20committment $\% 20$ to $\% 20$ gender\%20equality.pdf

Cash, Michaelia. 2014. Investing in Gender Equality at the G20 Leaders Summit. Ministerial Speech, 24 September. Available at: ministers. dpmc.gov.au/cash/2014/investing-gender-equality-g20-leaderssummit

Cash, Michaelia. 2017. Delivering Opportunities and Support for Australian Women. Media Release. Available at: ministers.dpmc. gov.au/cash/2017/delivering-opportunities-and-support-australianwomen. Media Background Brief. Available at: www.dpmc.gov.au/ sites/default/files/files/pmc/Accountability\%20and\%20reporting\%20 section/2017-18-budget-delivering-for-australian-women.pdf

Council of Europe. 2009. Gender budgeting: Practical implementation. Handbook. Council of Europe, Directorate General of Human Rights and Legal Affairs.

Dinh Huong, Lyndall Strazdins and Jennifer Welsh. 2017. 'Hourglass ceilings: Work-hour thresholds, gendered health inequities'. Social Science \& Medicine 176: 42-51. doi.org/10.1016/j. socscimed.2017.01.024

Dunning, Polly. 2017. 'When Having Separate Bank Accounts is the Opposite of Independence'. Sydney Morning Herald, 21 March. Available at: www.smh.com.au/lifestyle/life-and-relationships/whenhaving-separate-bank-accounts-is-the-opposite-of-independence20170320-gv26o5.html

Edwards, Meredith. 1981. Financial Arrangements within Families. Canberra: National Women's Advisory Council.

Edwards, Meredith. 2001. Social Policy, Public Policy: From problem to practice. Sydney: Allen \& Unwin.

Edwards, Meredith. 2010. 'In Search of Useful Research: Demand and supply challenges for policy makers'. Public Administration Today, v. 24 October-December. 
Eisenstein, Hester. 1996. Inside Agitators: Australian Femocrats and the State. Philadelphia: Temple University Press.

Government of Canada. 2017. 'Equal Opportunity: Budget 2017's Gender Impact Statement'. In Budget 2017-18. Available at: www.budget.gc.ca/2017/docs/plan/chap-05-en.html

Goward, Pru. 2004. 'Now everyone can focus on women'. The Age, 30 October.

Head, Brian. 2013. How do government agencies use evidence? Report for National Board of Health and Welfare, Stockholm, Sweden.

Henry, Ken et al. 2009. Review of Australia's Future Tax System: Report to the Treasurer. Australia's Future Tax System Review Panel (the 'Henry Review'). Available at: taxreview.treasury.gov.au

Heron, Alexandra, Rae Cooper and Gabrielle Meagher. 2017. 'Australia: The care challenge'. In Marian Baird, Michele Ford and Elizabeth Hill (eds), Women, Work and Care in the Asia-Pacific, pp. 167-181. Routledge: London and New York. Kindle Edition.

Keating, P.J. 1994. Working Nation: Policies and programs. White paper on employment and growth, presented 4 May. Canberra: Australian Government Publishing Service.

NFAW (National Foundation for Australian Women). 2015. A Gender Lens-Budget 2015-16. NFAW. Available at: www.nfaw.org

NFAW (National Foundation for Australian Women). 2017. A Gender Lens-Budget 2017-18. NFAW. Available at: www.nfaw.org/genderlens-on-the-budget/

Nutley, Sandra, Isabel Walter and Huw T.O. Davies. 2007. Using Evidence: how research can inform public services. University of Bristol: Policy Press.

OECD (Organisation for Economic Cooperation and Development). 2014a. Women, Government and Policy Making in OECD Countries. Paris: OECD Publishing.

OECD. 2014b. Balancing Paid Work, Unpaid Work and Leisure. Available at: www.oecd.org/gender/data/balancingpaidworkunpaid workandleisure.htm 
OECD. 2016. Gender Budgeting in OECD Countries. Public Governance and Territorial Development Directorate, 37th Annual Meeting of OECD Senior Budget Officials, Stockholm, 9-10 June.

Office for Women. 2006. Women '06: 2006-07 Budget Information. Canberra: Office for Women.

Office for Women. 2016. Women's Economic Security. Canberra: Department of the Prime Minister and Cabinet. Available at: www. dpmc.gov.au/office-women/economic-security

Productivity Commission. 2015. Childcare and Early Childhood Learning Final Report. Available at: www.pc.gov.au/inquiries/completed/child care\#report

Sawer, Marian. 1990. Sisters in Suits: Women and Public Policy in Australia. Sydney: Allen \& Unwin.

Senate Economic References Committee. 2016. Inquiry into Women's Economic Security in Retirement. Canberra: Commonwealth of Australia.

Sharp, Rhonda and Ray Broomhill. 2013. A Case Study of Gender Responsive Budgeting in Australia. Research Report: The Commonwealth Secretariat. Available at: www.asiapacificgender.org/ financing-accountability-partnership/case-study-gender-responsivebudgeting-australia

Treasury. 1985. Reform of the Australian Tax System: Draft White Paper. Australian Government: Canberra.

Treasury. 2017. Budget 2017-18. Australian Government: Canberra. Available at: www.budget.gov.au

Walby, Sylvia. 2005. 'Gender Mainstreaming: Productive Tensions in Theory and Practice'. Social Politics: International Studies in Gender, State and Society 12(3): 321-343. doi.org/10.1093/sp/jxi018

Watson, Sophie (ed.). 1990. Playing the State: Australian Feminist Interventions. London: Verso.

Whiteford, Peter. 2016. Should We Be Worried About Zero Net Taxpayers? TTPI Policy Brief 5/2016. Available at: taxpolicy.crawford. anu.edu.au/publication/9084/should-we-be-worried-about-zero-nettaxpayers 
This text is taken from Tax, Social Policy and Gender: Rethinking equality and efficiency, edited by Miranda Stewart, published 2017 by ANU Press, The Australian National University, Canberra, Australia.

dx.doi.org/10.22459/TSPG.11.2017.11 